Available online at: https://proceeding.researchsynergypress.com/index.php/rsfconferenceseries1

RSF Conference Series: Business, Management and Social Sciences

e-ISSN 2807-5803/ p-ISSN 2807-6699

Volume 1 Number 3 (2021): 285-291

\title{
Business Strategies and Digital Marketing Management in Desa Prima Sleman SMEs
}

\author{
Yuni Istanto', Dyah Sugandini'1 , Gunawan Nusanto², Windy Anindya Pamuji1, Trestina \\ Ekawati ${ }^{1}$ \\ 1Department of Management, Universitas Pembangunan Nasional "Veteran" Yogyakarta, Indonesia \\ 2Department of Mining Engineering, Universitas Pembangunan Nasional “Veteran”Yogyakarta, \\ Indonesia
}

\begin{abstract}
This review expects to give knowledge to SMEs in Sleman regarding how organizations seeking different techniques approach this advanced promoting issue. A definitive objective is to help SMEs in Sleman in the productive and viable execution of the system embraced by their organizations. The technology provided to SMEs planned in this research is a digital technology for product marketing and improving product quality and production. The population in this study were all SME's in Sleman. The census did sampling. The research approach is made by survey, observation, FGD, and in-depth interview. The overall hypothesis in this study is positively and significantly supported. The research that has been done shows that SMEs in Sleman have a marketing performance that is influenced by the types of digital marketing strategies and strategies. On the other hand, the performance of SMEs is influenced by marketing performance.
\end{abstract}

Keywords: marketing digital strategy, marketing performance, SMEs performance, strategy type

This is an open access article under the $\mathrm{CC}-\mathrm{BY}-\mathrm{NC}$ license

\section{INTRODUCTION}

Innovative advances cause organizations to have more technique choices and reinforce the organization's capacity to seek after some unacceptable one of a progression of grounded changes to a current general business methodology, yet with another conveyance. Simultaneously, much has been expounded on the rise of advanced promoting strategies. The Corona Virus Disease (COVID-19) pandemic has essentially affected the SME area in Indonesia. The undeniably enormous crown episode has at long last upset the promoting system at a critical point. The Ministry of Cooperatives and SMEs' gotten grumblings from 1417 SME's against Covid-19 since March 2020. SME's face a variety of clients and different requests, and picking the fitting key direction is basic to adjusting to the outside climate and getting market openings (Chen, Li \& Evans, 2012). To reduce market pressure, SMEs must choose a strategy that SME's implement for digital marketing.

Getting what key needs an organization has with respect to computerized showcasing, while every one of these strategic needs can be critical to any business, firmly proposes that the degree of significance of each will differ contingent upon the prerequisites hidden the fruitful execution of a specific technique. For instance, the difficulties and need levels an organization that centers vigorously around presenting another item (i.e., Miners or Analyzers) may have in building brand care could be much more vital than they would an association that bright lights on keeping a setup market (i.e., Low - cost safeguards or Separated protectors).

Corresponding author

Yuni Istanto, yuni.istanto@upnyk.ac.id

DOI: https://doi.org/10.31098/bmss.v1i3.330

Research Synergy Foundation 
Solid with this line of thinking is the possibility that diverse advanced promoting strategies will contrast in their viability in accomplishing those needs. However, not all advanced showcasing strategies are pretty much as viable as all conditions; further exploration is required on what systems are appropriate for SMEs to carry out in Do-It-Yourself during the Coronavirus pandemic to further develop SME's exhibition. This review means to give knowledge to SMEs in Do-It-Yourself on how organizations seeking after different techniques approach this advanced promoting issue, with a definitive objective of aiding SMEs in Do-It-Yourself in carrying out the systems embraced by their organizations productively and viably.

\section{LITERATURE REVIEW}

\section{Business Strategy and Digital Marketing Management}

During the web's business development period, many anticipated that its rise would lessen the decision of corporate showcasing procedures, accordingly successfully closing down some business methodologies (Porter, 2001). In opposition to those troubling forecasts, making plenty of new computerized promoting strategies doesn't seem to lessen cutthroat methodology freedoms to one minimal expense alternative, as Porter predicts. All things considered, this strategy seems to have reinforced the organization's capacity to seek after one of a progression of grounded changes to its current general business methodology, but with another conveyance. While much has been expounded on the development of advanced promoting strategies since Porter's articles (e.g., (Berthon et al., 2012); (Tiago \& Veríssimo, 2014), little consideration has been coordinated to how these strategies adjust inside the system of different business methodology. Furthermore, which computerized showcasing strategies are the best in supporting the execution of every one of the four business techniques? The term "strategy."

\section{Internet vs Digital Marketing}

The web is all the more a correspondence stage as opposed to a promoting device. It is a medium through which exchanges can be executed, and one-of-a-kind promoting strategies can be utilized. Strategies are the manner by which the picked methodology is executed. While this was completely perceived in 2001 in the year. Michael Doorman distributed fundamental articles on plan and the web over the earlier years, the number and refinement of web showcasing strategies have developed significantly. This strategy currently falls under the more extensive advanced promoting moniker. While there are numerous advanced showcasing strategies, we center around seven of the most widely recognized, as distinguished by autonomous innovation-centered exploration and promoting firm (Ascend2, 2019).

a. Content advertising: "a fundamental advancing methodology that bright lights on making and spreading significant, critical, and consistent substance to attract and hold a sensible crazy group, at last, to drive useful customer action" (ContentMarketing Organization, nd).

b. Engine optimization: "content and long haul and persistent improvement of computerized plan resources with the end goal of positioning as high as conceivable on internet searcher pages" (Key, 2017).

c. Email marketing: the demonstration of sending messages straightforwardly to possibilities and clients with opportune and significant data.

d. Search and social ads: the demonstration of putting advertisements with the goal that they show up at the highest point of search postings or in the sidebar on query items pages. These advertisements are connected to catchphrases and show up in indexed lists when explicit watchwords or expressions are gone into web search tools. 
e. Data-driven personalization: crowd division and dynamic depending on data about people as opposed to their recorded decisions.

f. Marketing technology usage: a bunch of programming and innovative devices utilized by advertisers to robotize or smooth out the promoting system, gather and break down information, and give different approaches to reach and draw in target crowds.

Online media promoting: anything where you pay a web-based media organization to show your substance (e.g., Facebook, Instagram, Twitter, Pinterest, Connected In, Snapchat)

\section{RESEARCH METHOD}

In light of the unbiased exploration, this examination is the examination to test the speculation. To test our speculation, this review embraced a poll study technique to gather information. Survey things incorporate foundation data, kind of technique, computerized advertising, and SME execution. In this review, the exploration methodology that will be utilized is overview research. According to Fink (2003), an outline collects information from or about people to portray, take a gander at, or explain their understanding, viewpoints, and lead. This review utilizes a quantitative methodology that underlines hypothesis testing through estimating research factors with numbers got from the circulation of exploration surveys and afterward breaking down information utilizing measurable systems. The populace is a speculation region comprising of items or subjects with specific characteristics and qualities dictated by analysts to be concentrated and afterward reached inferences (Sugiyono, 2015). The populace in this review were all UKM Desa Prima in Sleman.

\section{Attributes of Respondents}

The attributes of the respondents appear in Table 1. Most respondents are SME proprietors and directors.

Table 1. Attributes of respondents

\begin{tabular}{|c|c|c|}
\hline \multirow{3}{*}{ Gender } & Male & Percentage \\
\cline { 2 - 3 } & Female & $57 \%$ \\
\hline \multirow{3}{*}{ Age of Respondents } & $43 \%$ \\
\cline { 2 - 3 } & $\leq 30$ & $10 \%$ \\
\cline { 2 - 3 } & $30-39$ & $20 \%$ \\
\hline \multirow{3}{*}{ Position in business } & $40-49$ & $26 \%$ \\
\cline { 2 - 3 } & $\geq 50$ & $44 \%$ \\
\cline { 2 - 3 } & Owner & $52 \%$ \\
\cline { 2 - 3 } & Owner and Manager & $14 \%$ \\
\hline & Others & $30 \%$ \\
\cline { 2 - 3 } & Fashion & $26 \%$ \\
\cline { 2 - 3 } & Culinary & $33 \%$ \\
\cline { 2 - 3 } & Crafts & $23 \%$ \\
\cline { 2 - 3 } & Others & $17 \%$ \\
\hline
\end{tabular}




\section{Reliability and Validity}

The consistent strategy used in this audit is Partial Least Square (PLS). According to (Hair et al., 2014), PLS is one of the Structural Equation Modeling (SEM) techniques that can directly analyze latent variables, indicator variables, and measurement errors. PLS can be used with small sample sizes and can be applied to all data scales. The outer model or test of reflective indicators is evaluated through convergent validity, discriminant validity, and AVE. Meanwhile, the reliability test is seen from the composite reliability and Cronbach alpha values. Valid and reliable data is $>0.7$, and the expected AVE value is $>0.5$; each construct shown in table $1 \&$ table 2 has criteria above the expected standard.

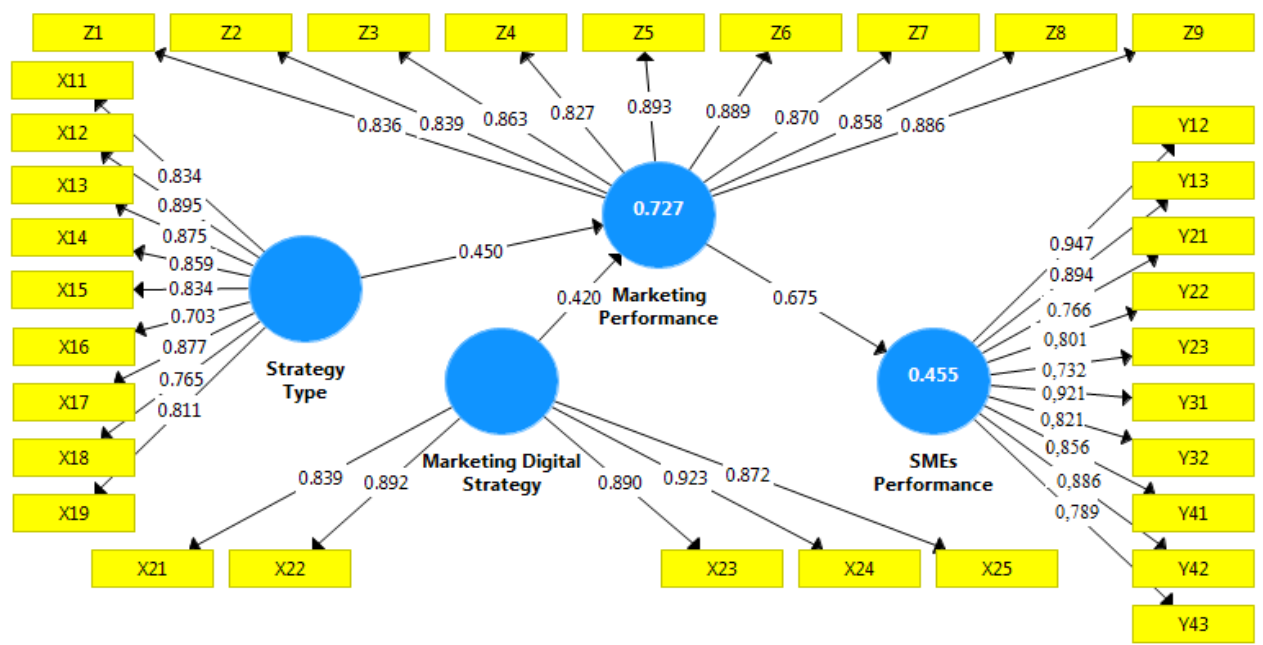

Figure 1. Results of Testing Model Algorithm

Table 2. Outer Loading

\begin{tabular}{|r|r|l|r|r|}
\hline & Marketing Digital_Strategy & Marketing_Performance & SMEs_Performance & Strategy_Type \\
\hline X11 & & & & 0,834 \\
\hline X12 & & & & 0,895 \\
\hline X13 & & & & 0,875 \\
\hline X14 & & & & 0,859 \\
\hline X15 & & & & 0,834 \\
\hline X16 & 0,839 & & & 0,703 \\
\hline X17 & 0,892 & & & 0,877 \\
\hline X18 & 0,890 & & & 0,765 \\
\hline X19 & 0,923 & & & 0,811 \\
\hline X21 & 0,872 & & & \\
\hline X22 & & & & \\
\hline X23 & & & & \\
\hline X24 & X25 & & & \\
\hline Y12 & Y13 & & & \\
\hline
\end{tabular}


RSF Conference Series: Business, Management and Social Sciences, Vol. 1 (3), 285-291

Business Strategies and Digital Marketing Management in Desa Prima Sleman SMEs

Yuni Istanto, Dyah Sugandini, Gunawan Nusanto, Windy Anindya Pamuji, Trestina Ekawati

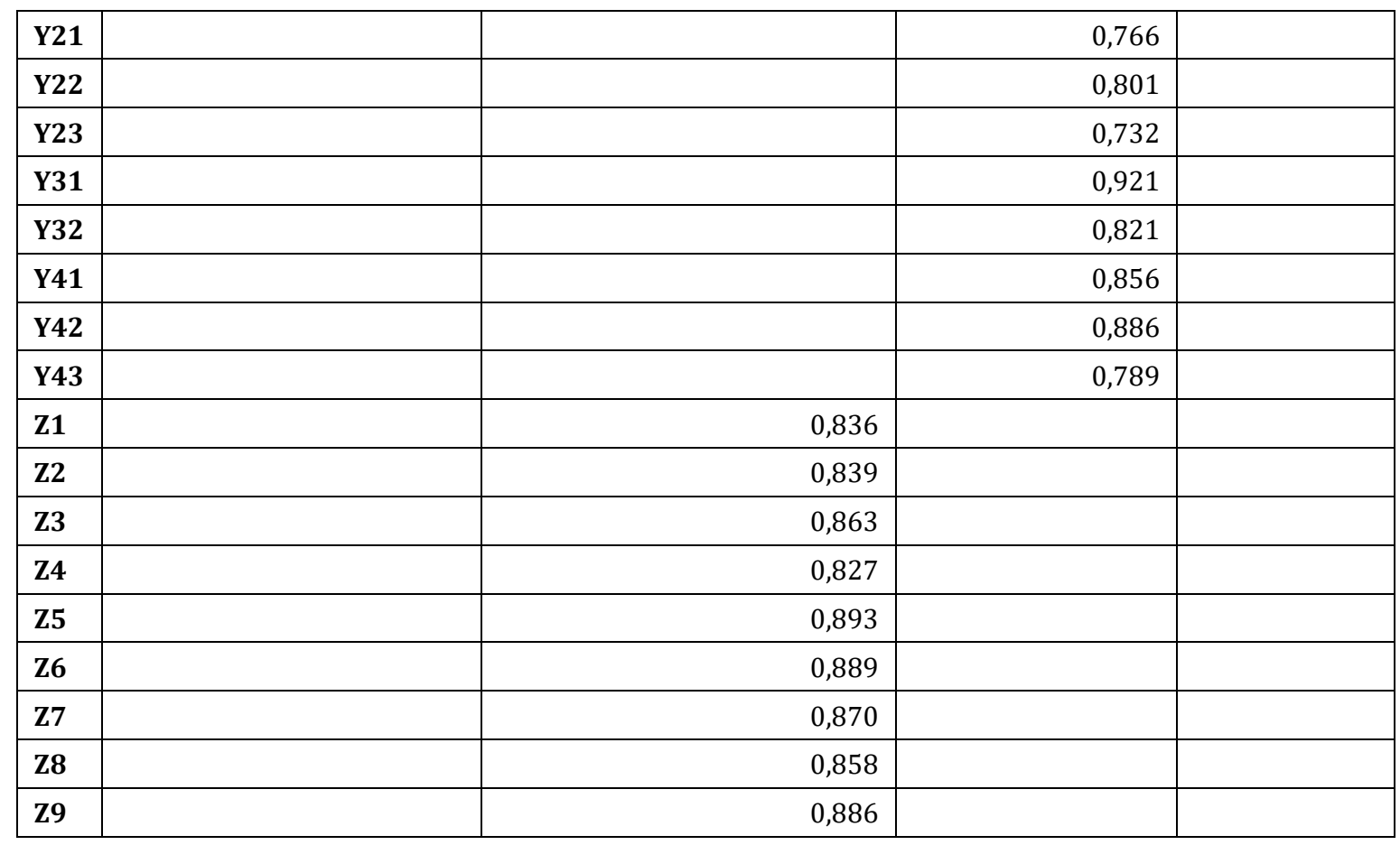

Table 3. Construct Reliability and Validity

\begin{tabular}{|l|r|r|r|r|}
\hline & \multicolumn{1}{|c|}{$\begin{array}{c}\text { Cronbach's } \\
\text { Alpha }\end{array}$} & \multicolumn{1}{c|}{$\begin{array}{r}\text { rho_ } \\
\text { A }\end{array}$} & $\begin{array}{l}\text { Composite } \\
\text { Reliability }\end{array}$ & \multicolumn{2}{c|}{$\begin{array}{c}\text { Average Variance } \\
\text { Extracted (AVE) }\end{array}$} \\
\hline $\begin{array}{l}\text { Marketing } \\
\text { Digital_Strategy }\end{array}$ & 0,930 & $\begin{array}{r}0,93 \\
1\end{array}$ & 0,947 & 0,781 \\
\hline $\begin{array}{l}\text { Marketing_Perform } \\
\text { ance }\end{array}$ & 0,957 & $\begin{array}{r}0,96 \\
1\end{array}$ & 0,963 & 0,744 \\
\hline SMEs_Performance & 0,935 & $\begin{array}{r}0,83 \\
1\end{array}$ & 0,944 & 0,733 \\
\hline Strategy_Type & 0,943 & $\begin{array}{r}0,94 \\
7\end{array}$ & 0,952 & 0,689 \\
\hline
\end{tabular}

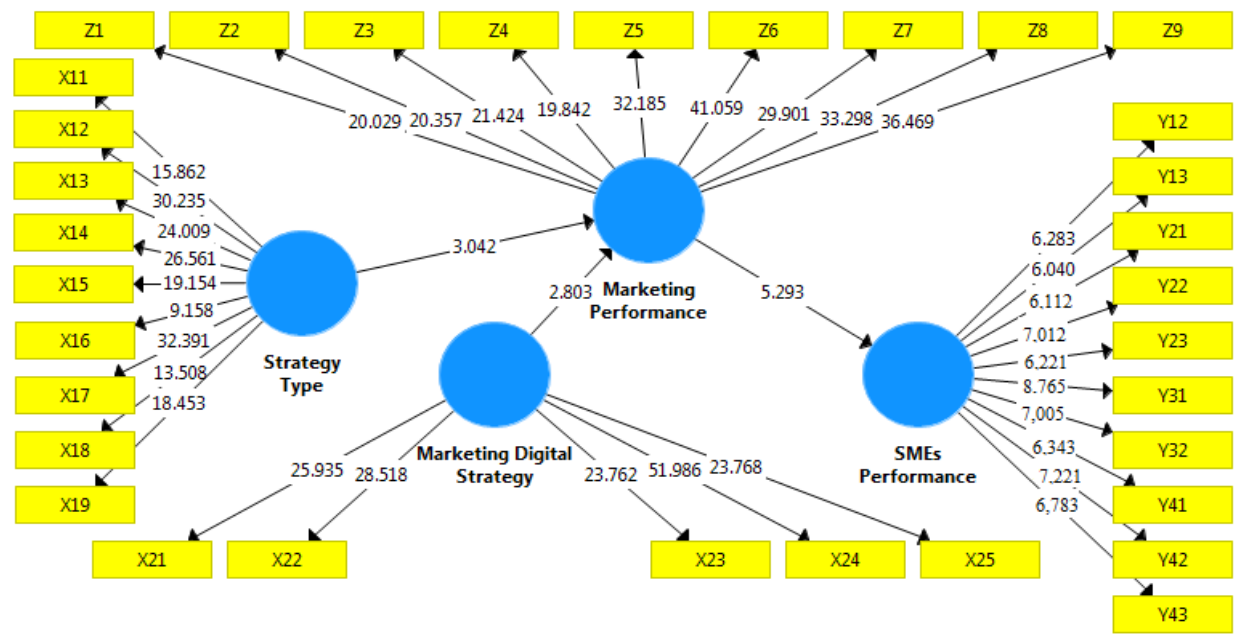

Figure 2. bootstrapping Model Testing Results 
Table 4. Patch Coefficient

\begin{tabular}{|l|r|l|l|l|l|c|}
\hline & $\begin{array}{l}\text { Original } \\
\text { Sample } \\
\text { (0) }\end{array}$ & $\begin{array}{l}\text { Sample } \\
\text { Mean } \\
\text { (M) }\end{array}$ & $\begin{array}{l}\text { Standard } \\
\text { Deviation } \\
\text { (STDEV) }\end{array}$ & $\begin{array}{l}\text { T Statistics } \\
\text { (|0/STDEV })\end{array}$ & $\begin{array}{l}\text { P } \\
\text { Values }\end{array}$ & $\begin{array}{l}\text { Supp } \\
\text { orte } \\
\text { d }\end{array}$ \\
\hline $\begin{array}{l}\text { Marketing } \\
\text { Digital_Strategy -> } \\
\text { Marketing_Performa } \\
\text { nce }\end{array}$ & 0,420 & 0,424 & 0,150 & 2,803 & $\mathbf{0 , 0 0 5}$ & Yes \\
\hline $\begin{array}{l}\text { Marketing_Performa } \\
\text { nce -> } \\
\text { SMEs_Performance }\end{array}$ & 0,675 & 0,678 & 0,128 & 5,293 & $\mathbf{0 , 0 0 0}$ & Yes \\
\hline $\begin{array}{l}\text { Strategy_Type -> } \\
\text { Marketing_Performa } \\
\text { nce }\end{array}$ & 0,450 & 0,447 & 0,148 & 3,042 & $\mathbf{0 , 0 0 2}$ & Yes \\
\hline
\end{tabular}

The aftereffects of quantitative examination in this review menu show that all theories have a positive and critical impact. The original sample values in H1 (0,450), H2 (0,420), H3 (0.675) have a positive value so that it shows a positive relationship. On the other hand, the t-statistics value is $>1.960$ and $\mathrm{p}$-values $>5 \%$. This means the hypothesis $\mathrm{H} 1$ ( $\mathrm{t}$-value $=3,042 / \mathrm{p}$-value $=0.002$ ), $\mathrm{H} 2$ ( $\mathrm{t}$-value $=2,803$ $/ \mathrm{p}$-value $=0.005), \mathrm{H} 3$ ( $\mathrm{t}$-value $=5.293 / \mathrm{p}$-value $=0.000$ ) is supported .

\section{FINDING AND DISCUSSION}

This study has tracked down a positive and huge connection between each hypothesis. The research results on hypothesis 1 indicate that the type of strategy affects marketing performance. Regardless of size, any for-profit enterprise aims to increase sales and maximize profits through a developed marketing strategy. Marketing strategy creates and maintains a competitive advantage in the most sustainable way (Bhattacharya et al., 2016). The results of research 2 show that digital marketing strategies affect marketing performance. Marketing strategy has always been a part of strategic planning in related business organizations. The initial step in developing a marketing strategy involves analyzing internal and external factors in the business environment to identify what the organization should do to maximize the existing situation (Ratten, 2016). The results of the study on hypothesis 3 indicate that marketing performance affects the performance of SMEs. Advertising execution is a basic component of the organization's exhibition overall on the grounds that the presentation of an organization can be seen from its promoting execution up until this point. Marketing performance is a concept to measure the marketing achievement of a company. Each organization is keen on knowing its accomplishments as an impression of the achievement of its business in market rivalry.

\section{CONCLUSION AND FUTURE RESEARCH}

\section{Conclusion}

The consequences of this review show that every one of the instruments utilized is solid. Overall, the overall hypothesis in this study is positively and significantly supported. The research that has been done shows that SMEs in Sleman have a marketing performance that is influenced by the type of strategy and digital marketing strategy. On the other hand, the performance of SMEs is impacted by marketing performance. 


\section{Further Research}

Based on the researcher's findings, this study has several limitations so that researchers can provide suggestions that are expected to be helpful for the future. First, the sample in this study was limited to a particular area, namely Sleman. Therefore, it is hoped that future researchers will be able to reach a larger size. Second, for SMEs in Sleman to use new technology more to support production facilities and be more aggressive in using digital marketing such as (Instagram, Twitter, Facebook, etc.).

\section{REFERENCES}

Ascend2 (2019) Digital marketing strategies: Survey summary report.

Berthon, P. R. et al. (2012) 'Marketing meets Web 2.0, social media, and creative consumers: Implications for international marketing strategy', Business Horizons, 55(3), pp. 261-271. doi: 10.1016/J.BUSHOR.2012.01.007.

Bhattacharya, M. et al. (2016) 'The effect of renewable energy consumption on economic growth: Evidence from top 38 countries', Applied Energy, 162, pp. 733-741. doi: 10.1016/J.APENERGY.2015.10.104.

Chen, Y. C., Li, P. C. and Evans, K. R. (2012) 'Effects of interaction and entrepreneurial orientation on organizational performance: Insights into market driven and market driving', Industrial Marketing Management, 41(6), pp. 1019-1034. doi: 10.1016/J.INDMARMAN.2012.01.017.

Fink, J. K. (2003)' Advances in the hereditary spastic paraplegias', Experimental Neurology, 184(SUPPL. 1), pp. 106-110. doi: 10.1016/j.expneurol.2003.08.005.

Hair, J. et al. (2014) A Primer on Partial Least Squares Structural Equation Modeling (PLS-SEM). California. USA: SAGE Publications, Inc.

Key, T. M. (2017) 'Domains of Digital Marketing Channels in the Sharing Economy', https://doi.org/10.1080/1046669X.2017.1346977, 24(1-2), pp. 27-38. doi: 10.1080/1046669X.2017.1346977.

Porter, M. E. (2001) Strategy and the Internet, Harvard Business Review.

Ratten, V. (2016) 'The dynamics of sport marketing: Suggestions for marketing intelligence and planning', Marketing Intelligence \&amp; Planning, 34(2), pp. 162-168. doi: 10.1108/MIP-07-2015-0131.

Sugiyono (2015) Metode Penelitian Pendidikan Pendekatan Kuantitatif, Kualitatis, dan R\&D. Bandung: Penerbit Alfabeta.

Tiago, M. T. P. M. B. and Veríssimo, J. M. C. (2014) 'Digital marketing and social media: Why bother?', Business Horizons, 57(6), pp. 703-708. doi: 10.1016/J.BUSHOR.2014.07.002. 